\title{
Children's Preconceptions about the Functioning of the Human Body
}

\author{
Andrea Dalajková, Petra Trávníčková
}

\begin{abstract}
This study is aimed at finding preconceptions of preschool children about the functioning of the human body. It is divided into three parts. The first part presents theoretical background and highlights the importance of children's preconceptions for the children's learning process. The second part presents a variety of empirical surveys that demonstrate possible methodological approaches. The third part presents qualitative research using conceptual mapping methods, analyses of children's drawings and interviews with children. Research findings are presented in the conclusion and some structures of children's preconceptions about respiratory, circulatory and digestive systems are described.
\end{abstract}

Keywords: Children's preconceptions; Giordan's allosteric model; conceptual mapping.

\section{Dětské prekoncepty o fungování lidského těla}

\begin{abstract}
Abstrakt
Tato studie se zabývá prekoncepty dětí předškolního věku o fungování lidského těla. Práce je rozdělena do tří částí. První část představuje teoretická východiska dětských prekonceptů a zdůrazňuje význam těchto kognitivních struktur pro proces učení se dětí. Druhá část představuje řadu výzkumných studií, které ukazují možné metodické přístupy k tomuto fenoménu v prostředí mateřské školy. Třetí část představuje kvalita-
\end{abstract}


tivní výzkum s využitím metod pojmového mapování, analýzy kresby dětí a interview s dětmi. V závěru této studie jsou představeny výsledky výzkumu a jsou popsány některé struktury dětských prekonceptů o dýchací, oběhové a trávicí soustavě.

Klíčová slova: dětské prekoncepty; Giordanův alosterický model; pojmové mapování. DOI: $10.5507 /$ epd.2020.004

\section{Introduction}

Preschool children already have different experiences and ideas about the world. They already have their own theories about different phenomena, and these built-in constructs guided by their own logic and meaning are very resilient (Turek, 2005). These theories are also called children's preconceptions. These are linked to the constructivist theory. This theory accepts the fact that the brain is dynamically changing and learning proceeds by transforming an individual's constructs based on experience (Bertrand, 1998). It is a concept of child thinking where children "construct" their own understanding of the world and relationships and objects. This is important for our study as it may relate to concepts of social and biological systems.

Nowadays, we can encounter the phenomenon of constructivism in education very often. Different strategies are presented to support children's learning through their own activity. A suitable platform for the development of children's activity in the context of their own learning is the inquiry-based science education, in which an individual gets to know the reality via relatively independent learning - which means the activity and immediate sensory experiences of children themselves. Teachers are subject to a several demands arising from the preparation of appropriate learning situations that allow the child to explore freely (Dostál, 2013). In this context, we are primarily interested in children's experiences that shape their own theory. A prerequisite for the development of children's preconceptions is the confidence of teacher that these concepts are meaningful to the child and his/her learning. In other words, it is important that the preschool teacher intentionally works with them.

\section{Theoretical background}

Children coming to kindergarten already have different experiences and ideas about the world. They have already formed their own theories about different phenomena, and these built-in constructs, guided by their own logic and mind, are very strong, determinative and absolutely relevant to the child (Turek, 2005). These are the tools of 
children's cognition, the only ones available to the child and the ones with which the children work when constructing their knowledge - children's preconceptions.

The children feel a constant need to explain the world around them. However, they do not possess enough experience to compare their statements and ideas to the relevant scientific fact. For this reason, they develop their own theories, which draw on their past experiences. However, these concepts of children are not mere meaningless fabrications arising from misunderstanding of the scientific fact and the lack of information. These are the instruments of childhood cognition, the only ones available to the child. Simultaneously, they meet all aspects of scientific theory. If a child is to explain his/her naive theory, s/he can describe it, explain it, predict what will happen, and even give instructions on how to do something (Gavora, 1992).

This implies that children's preconceptions are very important to the child, and if we ignore them, children can carry these concepts with them for a long time. Their explanation of various phenomena comes naturally to them and is comprehensible to them, while a scientific explanation is often incomprehensible and distant to them (Žoldošová, 2006). And that is why teachers should pay attention to children's preconceptions and why they should work with them and use them effectively in the educational process.

\subsection{How to Work with Preconceptions?}

From birth, human mind is focused on finding meaning in new experiences. The child creates an idea (children's preconception) based on a certain experience and does not change it until s/he finds a suitable incentive to modify it. The first step to disrupt his/ her idea is to confront it with the opinions of other children. When a child discovers that not everyone is of the same opinion, his/her idea naturally disrupts, because the child comes to understand its weaknesses. It is therefore necessary to create a conflict that will result in the change of children's construct.

There are different ways a teacher can respond to preconceptions during the lesson. In the context of the epistemological disturbance, the teacher may ignore the children's preconceptions and try to replace the children's inaccurate ideas with a relevant fact. In this study, however, the focus will be on Giordan's allosteric model, which respects and develops the existence of children's preconceptions (Bertrand, 1998). Giordan's allosteric model uses children's preconceptions in learning and sees them as decoding structures of an individual that help him/her to make sense of the information. Simultaneously, Giordan's allosteric model also mentions receiving structures that incorporate new information or create entirely new structures. In this context, preconceptions seen as learning tools that are constantly changing. His ideas are based on the theory of Jean Piaget. Just as Piaget uses the word assimilation in connection with the infiltration of information into structures that have already been formed, in the context of Giordan's model, we talk about deforming of cognitive structures (Bertrand, 1998). 


\subsection{Research on Children's Preconceptions about the Human Body}

Pondering about the research strategy, we analyzed selected studies on children's preconceptions about the human body. In preschool children, the most appropriate method for diagnosing children's preconceptions seems to be the interview, as it offers the freedom to ascertain children's subjective opinions, it allows to go in depth and remain silent or respond adequately to unexpected answers (Doulík, Škoda, HajerováMüllerová, 2008). Interviews are often complemented with the analysis of children's drawings. For children, drawing is a better medium for expressing their thoughts and ideas. Together with the interview, we were thus able to obtain a large amount of usable data (Škoda, 2011). The problem is that quality analysis of the drawing is a difficult task and requires prior knowledge of the assessor (Čáp, 2007). By analyzing the drawing and interviewing the child, the researcher clarifies the child's idea of a certain phenomenon. S/he can easily ascertain what it is being shown in the drawing and why. It is not possible just to look at the drawing and say that this is how the child imagines a certain phenomenon. It is often the case that what children explain, they cannot capture in the drawing, so oral explanation in the form of an interview is essential.

Another option is so-called conceptual mapping. This method is closely related to the structural component of children's preconceptions. If the method is used correctly and effectively, the conceptual map results in a graphical representation of partial structure of the children's concept of the diagnosed term (Doulík, Škoda, 2011). The benefit of this method is that we can capture how a child understands the term and even how s/he understands it in the relation to other terms (Doulík, Škoda, HajerováMüllerová, 2008).

In the studies presented further, the authors used methods of content analysis of children's drawings, interview, conceptual mapping and experiment. The following chart provides basic information about the researched studies. For each study, the year of publication, the objectives set by the authors, the research methodology and the main research findings are given. These studies will be discussed in the conclusion of our paper with the results of our research. 


\subsection{Research Survey on Children's Preconceptions about the Human Body}

\begin{tabular}{|c|c|c|c|}
\hline Year, Author & Aims & Methodology & Primary research findings \\
\hline $\begin{array}{l}2019 \\
\text { J. Andersson, } \\
\text { R. Löfgren, } \\
\text { T. lkona }\end{array}$ & $\begin{array}{l}\text { - To find out how children } \\
\text { describe internal structure } \\
\text { of the human body. }\end{array}$ & $\begin{array}{l}\text { - Qualitative study } \\
\text { - Children aged 4-13 } \\
\text { - Content analysis of chil- } \\
\text { dren's annotated drawings. }\end{array}$ & $\begin{array}{l}\text { Compared to recent studies, } \\
\text { children drew more organs, the } \\
\text { brain was indicated almost as often } \\
\text { as the heart, and a heart-shape } \\
\text { was given as a representative } \\
\text { symbol for it. } \\
\text { The results show that many } \\
\text { children have an unexpected } \\
\text { amount of knowledge about } \\
\text { human internal organs. }\end{array}$ \\
\hline $\begin{array}{l}2017 \\
\text { A. Wiegerová, } \\
\text { A. Dalajková }\end{array}$ & $\begin{array}{l}\text { - To find out about preschool } \\
\text { children's preconceptions } \\
\text { about human digestive } \\
\text { system }\end{array}$ & $\begin{array}{l}\text { - Qualitative study } \\
\text { - Content analysis of chil- } \\
\text { dren's drawing } \\
\text { - Interview with children } \\
\text { - Preschool children }\end{array}$ & $\begin{array}{l}\text { Furthermore, research by Pupala } \\
\text { and Osuská (1997) shows that the } \\
\text { term "intestine" does not appear } \\
\text { in the testimonies of children, as } \\
\text { opposed to the aforementioned } \\
\text { research, where this term does } \\
\text { appear. }\end{array}$ \\
\hline $\begin{array}{l}2011 \\
\text { G. Óskarsdóttir, } \\
\text { B. Stougaard, } \\
\text { A. Fleischer, } \\
\text { E. Jeronen, } \\
\text { F. Lützen, } \\
\text { R. Kråkenes }\end{array}$ & $\begin{array}{l}\text { - To find out about preschool } \\
\text { children's preconceptions } \\
\text { in Scandinavian countries } \\
\text { about the human body, for } \\
\text { example the structure and } \\
\text { location of bones and or- } \\
\text { gans (heart, lungs, stomach, } \\
\text { brain etc.) }\end{array}$ & $\begin{array}{l}\text { - Qualitative study } \\
\text { - Children (aged 6) from } \\
\text { Denmark, Faroe Islands, } \\
\text { Greenland, Iceland and Nor- } \\
\text { way } \\
\text { - Content analysis of chil- } \\
\text { dren's drawings } \\
\text { - A specialized scale question- } \\
\text { naire } \\
\text { - Interview with children }\end{array}$ & $\begin{array}{l}\text { The results show that there are } \\
\text { similarities among Nordic children's } \\
\text { ideas about the human body and } \\
\text { the results are consistent with the } \\
\text { results of other studies. The results } \\
\text { show that most children did not } \\
\text { draw any connecting lines between } \\
\text { the organs in their drawings. }\end{array}$ \\
\hline $\begin{array}{l}2000 \\
\text { N. Toyama }\end{array}$ & $\begin{array}{l}\text { - To find out how preschool } \\
\text { children and young school } \\
\text { children describe biological } \\
\text { phenomena connected with } \\
\text { eating and breathing. }\end{array}$ & $\begin{array}{l}\text { - Qualitative study } \\
\text { - Children aged 4,5,7 and } 8 \\
\text { - A series of } 5 \text { experiments }\end{array}$ & $\begin{array}{l}\text { The results show that children } \\
\text { identify the cause of biological } \\
\text { damage to the human body as the } \\
\text { lack of food and air. } \\
\text { Children also recognized that food } \\
\text { was changing in the body, but } \\
\text { rarely was spontaneously related to } \\
\text { biological transformation. } \\
\text { Kindergarten children and } \\
\text { elementary school pupils assumed } \\
\text { that the air inside the body would } \\
\text { become warm and colour. }\end{array}$ \\
\hline
\end{tabular}




\section{Methodology}

The research is qualitative and deals with children's preconceptions about the functioning of the human body, respectively the functioning of individual organ systems. Prior to the research, the following objectives were set: (1) to find out what preconceptions about the human body preschool children have; (2) to describe some preschool children's preconceptions about the functioning of the human body; and (3) to describe the structure of preconceptions in a selected group of preschool children. The main research question: "What are the preconceptions about the human digestive system?" is based on the main research objective.

As the research participants were preschool children, the method of conceptual mapping, analysis of children's drawings and interviews were chosen. Conceptual mapping is a research method that is used to determine children's understanding of various phenomena. The benefit of this method is that it enables to capture not only how a child understands a particular term, but also how it interacts with other terms in their minds (Doulík, Škoda, Hajerová-Müllerová, 2005). Ideally, the conceptual map is a graphical representation of partial structure of the children's concept of the phenomenon (Škoda, Doulík, 2011).

Empirical research was carried out in a homogeneous class in a kindergarten in the Zlín region. The research group consisted of preschool children, specifically, 18 children aged 5 to 6 participated in the research, 11 boys and 7 girls. All participants attended the same class. Part of the research with children was obtaining the parental informed consent.

\subsection{Research Implementation}

The research was carried out individually with each participant. The researchers gave each child a paper with an outline of a human body. In this outline, children drew the systems that we can find in the human body, namely respiratory, digestive and vascular. The child then described parts of all the systems and explained how it functions.

\section{Main Research Findings}

The research results were interpreted via diagram that explains the structure of some of the children's preconceptions.

Diagram 1 presents a structure of preschool children's preconceptions about the human digestive system. 


\section{Diagram 1}

Children's preconceptions about the function of the human digestive system

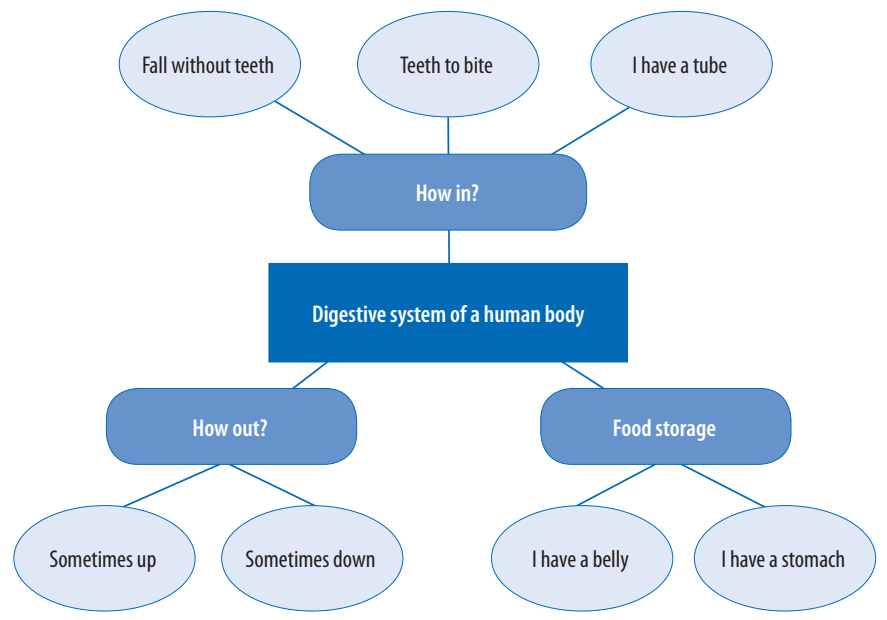

\section{HUMAN DIGESTIVE SYSTEM}

Most frequently, the children described the outline in which the organs were drawn as "a human" or a "human figure". There were also answers like "figure", "body of the figure". Here we came to the first finding. Understanding of the digestive system in the case of participants who likened the outline to a "figure", was further from reality.

How in? Overall, we can state that the preschool children imagine the digestive system being composed of three parts. First group represents children's ideas about how food gets from the mouth further into the body. When asked: "What do you think happens to an apple when you eat it," the children spoke about the apple falling into the abdominal cavity (abdomen, stomach or body). Most participants first mentioned a certain "fall" of food inside and only later returned to an idea of a "tube", which is to indicate the relevant term "esophagus".

Food storage. This category can be divided in two parts. While one half of the participants think that food is stored in the "belly", the other half already work with the term "stomach". Participants described various processes that can take place in the abdominal cavity. Some participants did not go further. They described that food remains in the abdominal cavity, dissolves there, or collects there.

How out? Here are preconceptions about how food can get out of the body. Several participants began to spontaneously describe vomiting and its causes, but most of them focused on excretion. In three cases the term "intestine" was recorded (Wiegerová, Dalajková, 2017). 
Diagram 2 presents a structure of preschool children's preconceptions about the human circulatory system.

\section{Diagram 2}

Human circulatory system

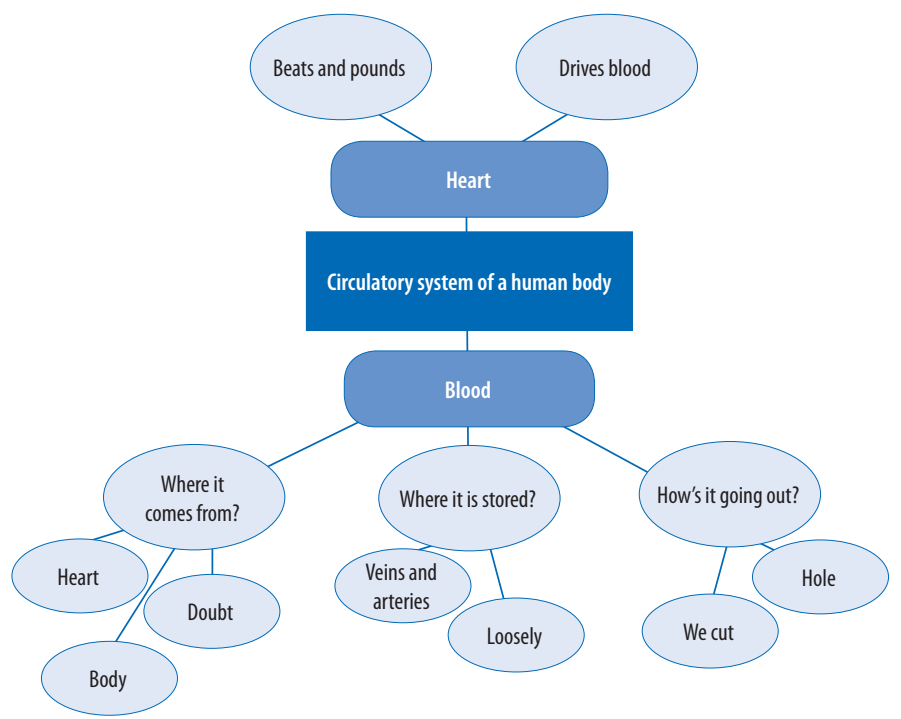

\section{HUMAN CIRCULATORY SYSTEM}

In the interview, preschool children most often mentioned the heart and blood circulating in the arteries. Therefore, the main category is further divided into two subcategories.

Heart. Preschool children most often claimed that the only function of the heart is that it beats/pounds/beats. Some children mentioned that the heart also drives blood. In the subcategory "Heart Functions for Life", participants' most frequent answers are presented. Most of them also talked about the importance of heart, "if it didn't beat, we would die".

Blood. Children often talked about where the blood comes from, where it is stored, and how it gets out of the body. Some children mentioned that blood comes from the heart, others stated that it is stored in the veins and arteries. The last group of children talked about blood being stored freely in the body. Nevertheless, they all agreed that the blood is important and vital to the human body. 
Diagram 3 presents a structure of preschool children's preconceptions about human respiratory system.

\section{Diagram 3}

Human respiratory system

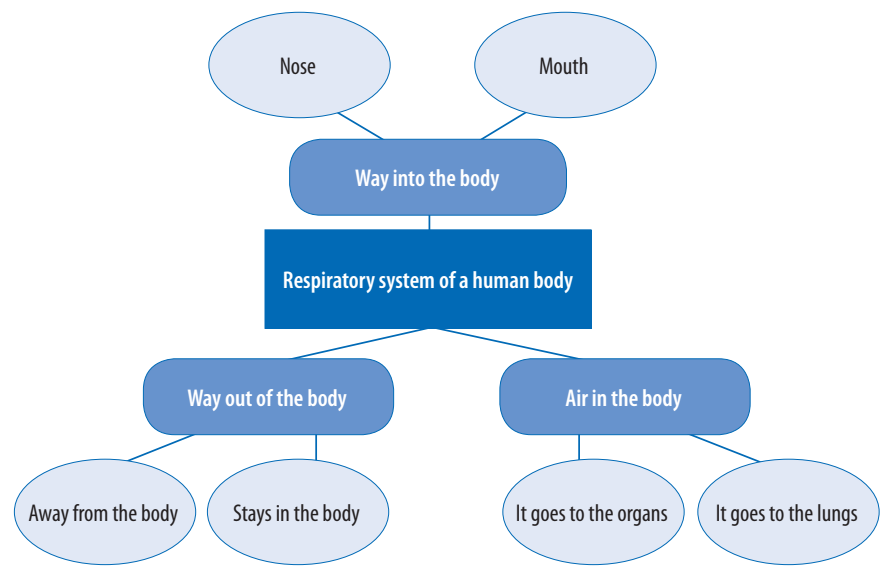

\section{HUMAN RESPIRATORY SYSTEM}

Considering all interviews conducted with preschool children, we can state that children imagine the respiratory system consisting of three parts. The first part focuses on how the air enters the body, the second on how the breathing process works in the body and the last describes how the air gets out of the body. Some children in this section claim that the air does not leave the body at all.

Into the body. In the first part, participants mainly described how the air gets into the body and via what organs. One group of children reported that the air would reach the body through the nose, mouth, or both nose and mouth.

Air in the body. In the second part the children focused on the process of breathing, for example how the air travels in the body. Here the answers varied because each participant imagined the overall breathing process differently. More than half children reported that the path of the air begins in the mouth or nose and then continues to other parts of the body, such as the heart, lungs, belly, or even the brain. One of the participants perceives the breathing process as the air entering the lungs, from where it is further taken by the corpuscles.

Out of the body. The last part focused on how the air leaves the body. Some participants reported that the air gets out of the body, mostly in the same way as it gets inside, but 
some children claimed that the air remains in the body and in the already mentioned organs.

Very often the participants mentioned the terms "stomach" or "abdomen" during the research. This notion arose because when they breathe, the abdominal cavity moves and, as a result, these organs are needed for breathing, and are, in their opinion, an essential part of the respiratory system.

\section{Conclusion}

The present study focused on the detection and analysis of preschool children's preconceptions about the functioning of the human body. A many of researchers have researched this phenomenon in the recent years, because it is becoming clear how important these preconceptions are for children's learning. In our study, we examined how preschool children describe the functioning of the digestive, respiratory and circulatory systems. The next step of the empirical research is to collect data on other organ systems of the human body, to use different research methods that will enable a better understanding of children's preconceptions in this area, and then focus on kindergarten teachers and their didactic activities in the context of developing and supporting children's preconceptions.

\section{Acknowledgements}

The authors wish to thank all students and their supervisors who assisted in the data collection process for this study. The authors thank to Adriana Wiegerová, Anna Koflerová, Pavlína Špičáková and Šárka Vyškovská.

\section{References}

Andersson, J., Löfgren, R., \& Tibell A. E., L. (2019). What's in the body? Children's annotated drawings. Journal of Biological Education 54(2), 176-190. DOI: 10.1080/00219266.2019.1569082.

Bertrand, Y. (1998). Soudobé teorie vzdělávání. Praha: Portál.

Čáp, J., \& Mareš, J. (2007). Psychologie pro učitele. Praha: Portál.

Gavora, P. (1992). Naivné teorie dietata a ich pedagogické využitie. Pedagogika, 42(1), 95-102.

Gellert, E. (1962). Children's conceptions of the contect and functions of the human body. Genetic Psychology Monographs, 65, 293-405.

Dostál, J. (2013). Badatelsky orientovaná výuka jako trend soudobého vzdělávání. e-Pedagogium, 3, 81-93. 
Doulík, P. (2005). Geneze dětských pojetí vybraných fenoménů. Ústí nad Labem: Univerzita J. E. Purkyně.

Doulík, P., Škoda, J., \& Hajerová, L. (2005). Výzkumné metody použitelné k diagnostice dětských pojetí. Technológia vzdelávania, 13(8), 2-9.

Óskarsdóttir, G., et al. (2011). Children's ideas about the human body - A Nordic case study. Nordic Studies in Science Education, 7(2), 179-189.

Pupala, B., \& Osuská, L.. (1997). Vývin detských koncepcií o tráviacej sústave a trávení. Psychológia a patopsychológia dietata, 1, 35-46.

Škoda, J., \& Doulík, P. (2011). Psychodidaktika: metody efektivního a smys/uplného učení a vyučování. Praha: Grada.

Toyama, N. (2000). "What are food and air like inside our bodies?": Children's thinking about digestion and respiration. International journal of behavioral development, 2(24), 222-230.

Turek, I. (2005). Inovácie v didaktike: príspevok k realizácii projektu Milénium vo vyučovacím procese na základných a stredných školách. Bratislava: Metodicko-pedagogické centrum v Bratislavě.

Wiegerová, A., \& Dalajková, A. (2017). How Food is Processed in the Human Body or Children's Concepts of How the Digetive Systém Works. Procedia - Social and Behavioral Sciences, 237, 1582-1587.

Žoldošová, K. (2006). Východiska primárného prírodovedného vzdelávania. Trnava Bratislava: SAV.

\section{Contacts:}

PhDr. Andrea Dalajková

PhDr. Petra Trávníčková

Tomáš Bat̉a University in Zlín,

Faculty of Humanities, Department of School Education

Štefánikova 5670, Zlín 76001

e-mails:dalajkova@utb.cz; ptravnickova@utb.cz

PhDr. Andrea Dalajková graduated from the bachelor study program Teacher Training for Kindergartens at Tomáš Bata University in Zlín and she also completed her master's degree in Preschool Pedagogy. She worked for several years at University Kindergarten and is currently an academic worker at the Institute of School Education.

PhDr. Petra Trávníčková graduated from the bachelor study program Teacher Training for Kindergartens at Tomáš Bata University in Zlín. She also completed her master's degree in Preschool Pedagogy. She is currently an academic worker at the Institute of School Education and is also a student of the Doctoral degree program Pedagogy at Tomáš Bat’a University in Zlín. The basic area of her professional interest is the development of science literacy of preschool and younger school children. 